Extensive open space lands, owned and managed by public entities in California are often managed with grazing livestock. Public land managers use grazing to manage vegetation for fire fuels, watershed protection, wildlife habitat and invasive species control (Huntsinger et al. 2007). A well-managed livestock grazing program can be effective for vegetation management and at the same time compatible with public access and recreational activities (Barry 2014).

Since beef cattle make up most of the livestock grazing on public lands in California (other common grazers include sheep, goats, dairy cattle, and horses), we decided to go right to the source to give you an idea of cattle's place and role on publicaccess lands. Here, then, is an account of a year's life on public lands, as related by one particularly eloquent beef cow.

\title{
UNDERSTANDING WORKING RANGELANDS A Year in the Life of a Beef Cow
}

\section{H.}

i there, human. Welcome to my home on the range. You're

probably wondering what I'm doing out here in this park. Well, I'm just doing my job, which is to give birth each year to a calf and raise it for beef production and eat weeds and grass to help maintain wildlife habitat and a healthy park landscape.

My "cowleagues," the other mother cows and I, and our calves make up the cow-calf herd in this park. You might ask how we got here. Like many of you, my bovine ancestors immigrated to California from Europe and Africa. The early Spanish brought livestock along with them as their food supply and the foundation for an economy in the New World. Under Mexican rule, the land was divided into "ranchos," and cattle were raised for food as well as for tallow and hides. These products supported the beginnings of a new state and were exported and traded. The Gold Rush brought thousands of people to California. They brought their livestock and cattle with them and the demand for beef soared. Spanish breeds of cattle, Corrientes, were replaced with English breeds, like Angus and Hereford. The ranchos were gradually transformed into ranches (see UC ANR Publication 8528 in this series, Bay Area Ranching Heritage, http://anrcatalog.ucanr.edu/Details.aspx?itemNo=8528) Most park and open space preserves in California were former ranches. Vegetation on much of this land is still managed by my cowleagues and I, much like it was when it was a privately owned ranch.

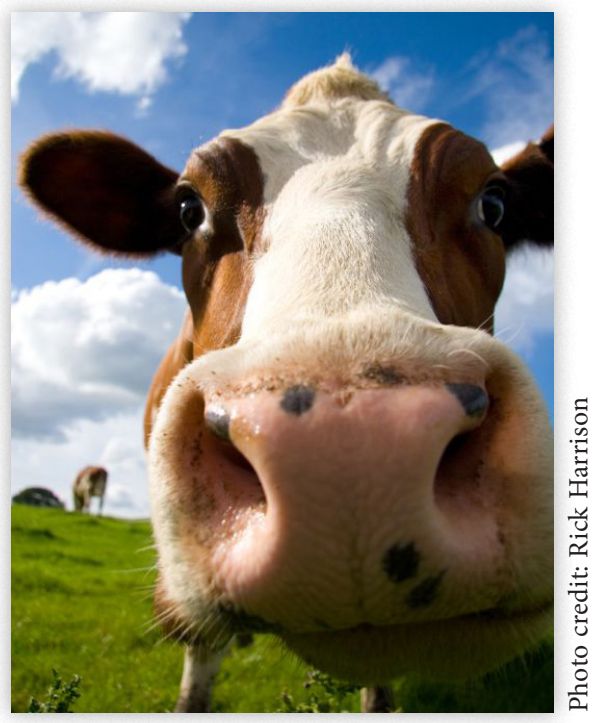

SHEILA BARRY, University of California Cooperative Extension County Director and Livestock Range Management Advisor, San Francisco Bay Area; STEPHANIE LARSON, University of Cooperative Extension County Director and Livestock Range Management Advisor, Sonoma County; and LISA BUSH, Rangeland Consultant 


\section{Cow-Calf Operation (Business)}

My herd includes cows like myself, replacement heifers, and of course bulls so we can produce calves for beef production. Although we produce milk and nurse our calves, we are not dairy cows and do not provide milk or cheese that you might buy in the store. As adult cows, we weigh about 1,390 pounds each. In rangeland management calculations, an adult cow with or without a nursing calf is considered to be 1 animal unit (AU). A weaned calf weighs from 500 to 700 pounds and is considered to be $0.5 \mathrm{AU}$.

Rangeland managers generally need to allow about 10 to 30 acres of rangeland per $\mathrm{AU}$ in order to have enough forage to maintain a cow-calf operation in the Bay Area or the Sierra Foothills. The actual carrying capacity of any particular acreage depends on that property's annual forage production, which is in turn relies on local precipitation, temperature, soil characteristics, plant reside, and site characteristics such as slope, tree cover, access to water, and the presence of noxious weeds.

Every year my cowleagues and I wean one calf each and then give birth to another. We live out here on the range all the time, eating grass and other plants and recycling nutrients. By eating the forage grasses that would otherwise grow tall enough to crowd and shade out native plants, we improve habitat for many native plants and animals (see UC ANR Publication 8517 in this series, The Benefits of Livestock Grazing California's Annual Grasslands, http://anrcatalog.ucanr.edu/Details.aspx?item No=8517). We also reduce the risk of catastrophic wildfire by eating grass and other plants that could otherwise become fine fuels.

In case you're wondering why we are out here even in the winter when it's muddy, the answer is simple: this is our home. Many of us in grazing herds have nowhere else to go, and the grass out here is nutritious and plentiful. Every month, we each eat about 1,000 pounds of grass and other plants (forage). That's roughly 2.5 percent of our body weight every day! We also drink from 5 to 15 gallons of water each day, depending on the heat and whether we're nursing calves.

Here's what happens in the production cycle each season.

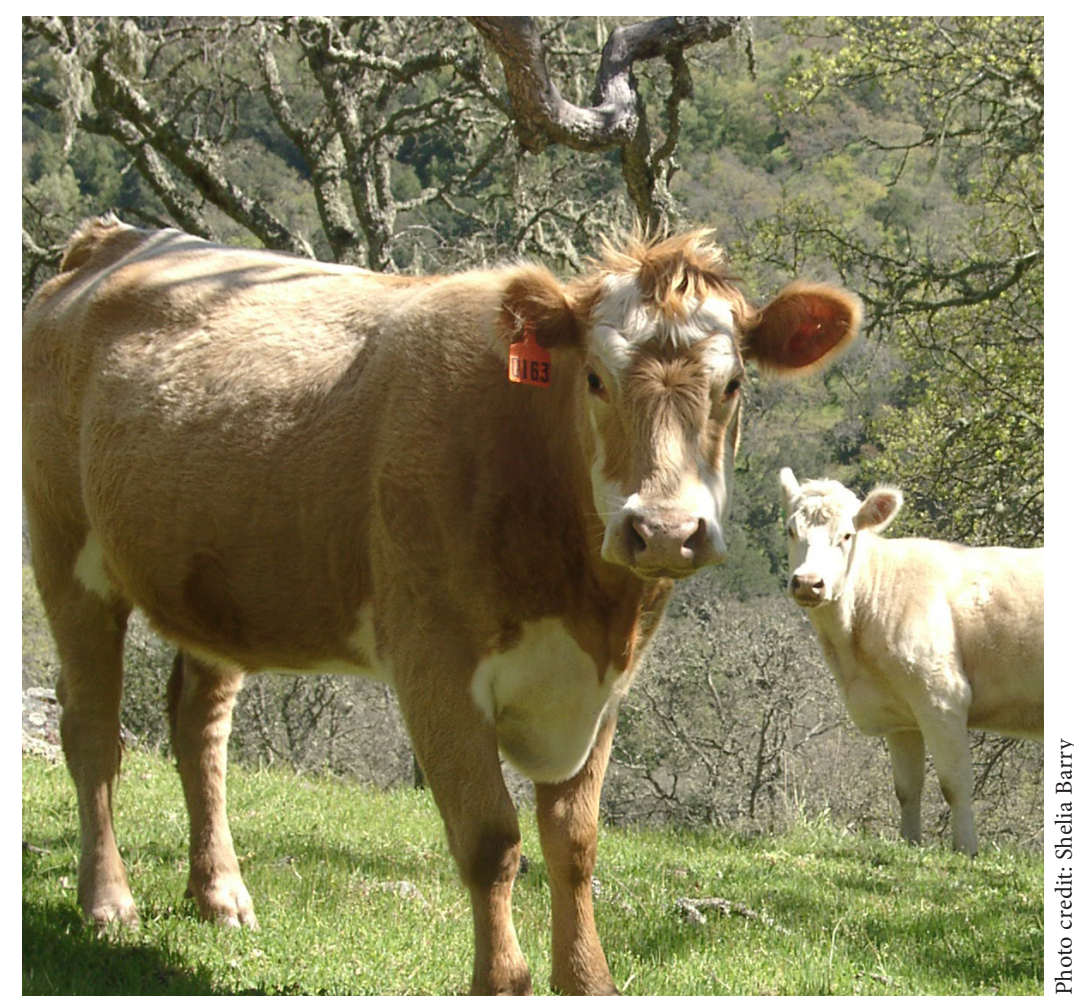

Fall

Across California's grasslands, our calves are usually born between August and November. We give birth, or "calve," in the fall so that by spring our calves will be old enough to graze and grow, right when the spring forage starts growing fast. Male calves are generally castrated within their first three months; that makes them more calm and prevents them from breeding their sisters. After castration, the males are called steers.

Have you noticed our eartags and brands? Branding and eartagging is done when calves are small, often at the same time as when the male calves are castrated. Brands and eartags identify us so if one of our calves strays onto the neighbor's range, they'll know it isn't theirs and know where to return it. Our calves also get vaccinations at that time to prevent disease. 
Winter

In November or December when our calves are just a couple of months old, the rancher puts a bull out here to breed with us. Our gestation period is just about the same as a human's -9 months.

Like any mother, cows like me are very protective of our young, so please don't get too close to me or my calf! (See UC ANR Publication 8516 in this series, Sharing Open Space: What to Expect from Grazing Livestock, http://anrcatalog.ucanr.edu/ Details.aspx?itemNo=8516.)

\section{Spring to Summer}

Our new calves stay with us for about 9 or 10 months until they are weaned, that is, separated from us mother cows and our milk

\section{Eartags and Brands}

An eartag can have the individual cattle number, an indication of the ranch the cattle belong to, or it can just be blank. Blank eartags typically contain insecticide to keep flies and ticks off of cattle. Eartags are not considered a legal form of livestock identification like brands. Brands are registered each year with the State of California's Bureau of Livestock Identification, and they constitute legal evidence of ownership. Brands have been used in California to identify cattle and protect owners from animal loss for over 150 years. The oldest current brand in California has been in continuous use in Monterey County since 1848. Ranchers apply legal brands using a hot iron or a chemical compound.

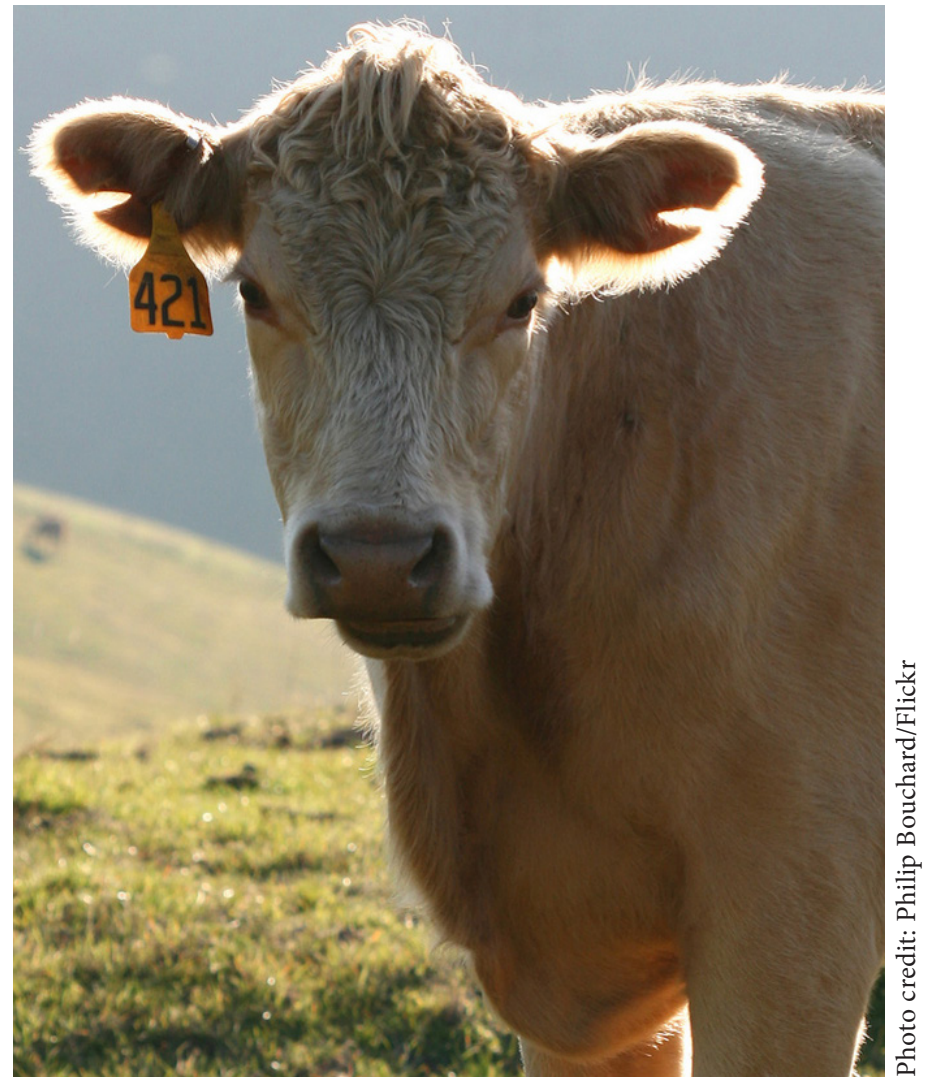

supply. The rancher will keep a few female calves (called heifers) to replace some of the mother cows who are getting too old to produce healthy calves. The rest of the calves are sold off in June or July. Our rancher says the calves are the product he uses to make his living. He gets his paycheck once a year, when the calves are sold to cattle buyers.

\section{Late Summer to Fall}

Since by this time our calves have been weaned and sold, we get a couple of months off before the whole cycle starts again in the fall.

\section{Supplemental Hay or Protein Supplement}

In the late summer when we are close to giving birth, some of our ranchers start giving us hay or other supplements to eat along with the dry grass available on the rangeland. Supplements such as protein blocks (a dark, hard substance) are provided in tubs. Liquid protein is another supplement, and the rancher give it to us in a big covered tub with a wheel in the center. Supplemental feeding usually continues through early winter. During this period, we need good nutrition as we nurse our newborn calves and begin our next pregnancy. The grass at that time of year is typically low in available nutrients and may be sparse. How much supplemental hay or protein we need depends on the quality of the dry grass, which declines as the dry season gets longer. If fall rains are late to come or if spring rains ended early, we'll have a longer dry season, and the grass for much of the year will be short in supply and short in nutrients, especially in protein (see UC ANR Publication 8529 in this series, Grazing Systems Management, http://anrcatalog.ucanr. edu/Details.aspx?item $\mathrm{No}=8529$ ).

Hay and protein are expensive and the rancher's profit margin for beef production is slim; for these reasons, many ranchers are conservative in how many cattle they are willing to graze, since they want to avoid the need for supplemental hay. Feeding hay or any feedstuff on a regular basis may be especially impractical on grazing lands that are too far away from the rancher's headquarters. However, ranchers can use extra feed, hay, or protein supplements, as a tool for attracting cattle to a different, preferred grazing area. 
Hay can also work as a lure to gather cattle together for vaccination, branding, or shipping.

\section{Producing Beef and By-Products}

You might be wondering how our calves, which weigh 500 to 700 pounds when they leave our grazing land, get to their market weight of 1,100 to 1,200 pounds. Well, that can happen in a few different ways.

\section{Grass-Raised, Feedlot Finished}

Most of our calves are "finished" in a feedlot after they leave the grazing lands. Some might be shipped to irrigated summer pastures or higherelevation rangelands first, to a stocker operation, but others will go straight to the feedlot. There is only so much feedlot capacity in California, so our calves may be shipped to other states such as Colorado, Kansas, or Nebraska, and put "on feed" there. They usually weigh around 900 pounds when they arrive at the feedlot. For

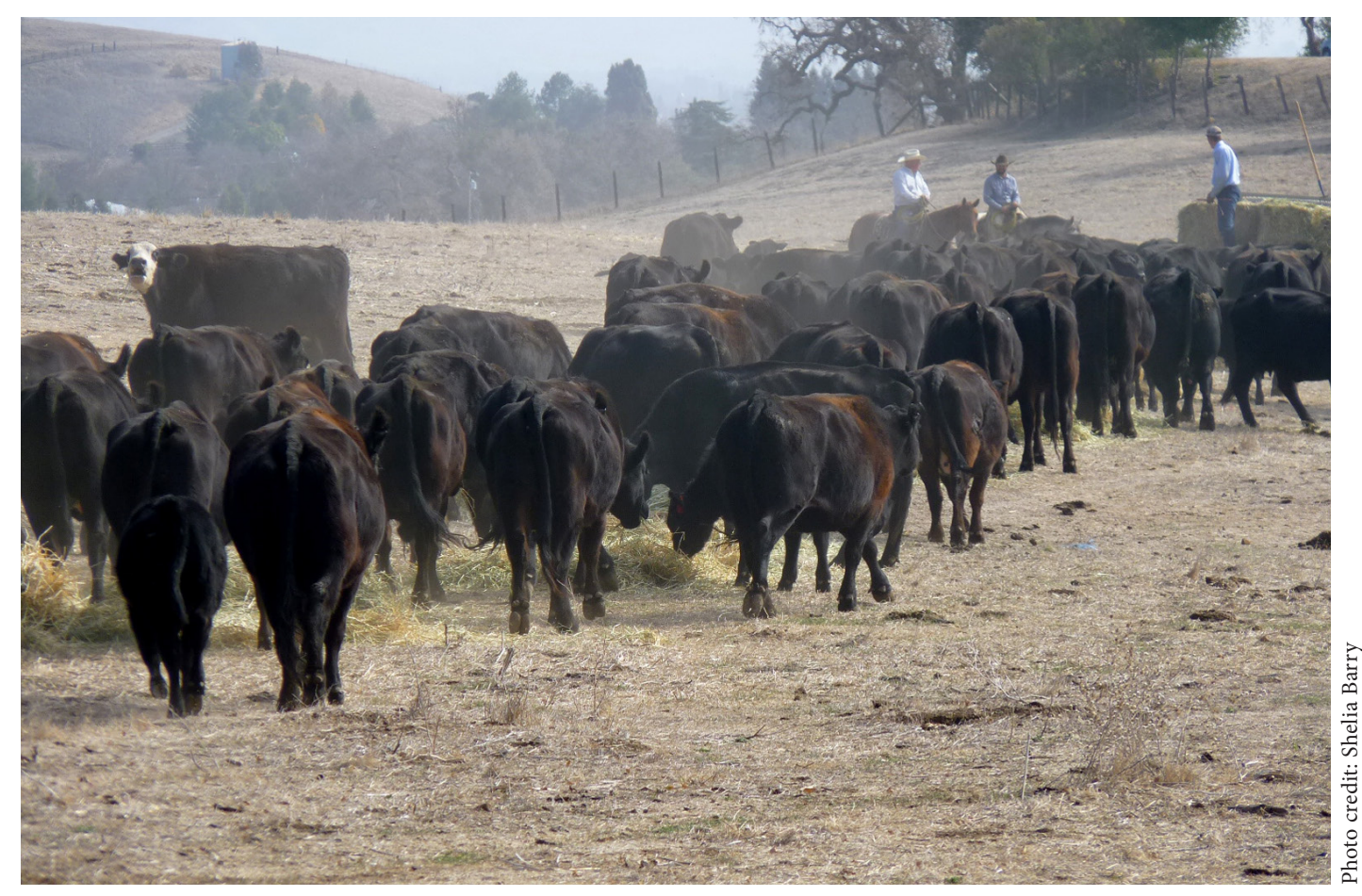
3 or 4 months they are fed a grain-based diet formulated to maximize weight gain and minimize cost. A grain-fed calf gains an average of more than 3 pounds each day! Their fatto-muscle ratio also increases, and later on that will translate into tenderer, better-tasting meat. Feedlot calves are finished to a weight of about 1,200 to 1,400 pounds and then slaughtered.

\section{Stocker Operation}

Some ranchers keep their weaned calves on the grazing land or acquire other young, weaned calves, known as "stockers." Stockers usually begin as 500- to 700-pound calves. The rancher's profits are based on increasing that weight before they are sold, so the idea is to fatten up the stocker calves on spring grass that is growing naturally on the rangeland. Stockers aren't normally fed supplemental hay; it's too expensive. On annual rangeland in California, stockers are typically kept for about 6 months during the growing season. You might think this kind of seasonal grazing

by stockers would be better for park land management, but stockers can actually make management more difficult because they are unfamiliar with their new surroundings, and that makes their behavior more unpredictable (see UC ANR Publication 8516 in this series, Sharing Open Space, http://anrcatalog.ucanr.edu/ Details.aspx?itemNo=8516). For example, stockers may be more curious and less timid than longer-resident cattle and may come closer to park visitors. They may also be easily spooked when they are in large groups, so hikers need to take extra care when approaching them.

\section{Other Ways to Produce Beef}

More and more ranchers today are producing grass-fed, grassfinished beef, and some ranchers raise stocker cattle instead of running a cow-calf operation, or run both operations at the same time. In addition, more than half of the beef and beef by-products 
produced in California today comes from dairy cattle. Here's a short description of how those operations work.

\section{Grass-finished operation (business)}

All beef calves are raised on grass (grass-fed). However, a small number of ranchers continue to raise their calves on grass after weaning, rather than selling them for finishing, and they can keep them on grass until they are heavy enough for processing. This is called a "grass-finished" operation. This type of beef cow production system works the same way as a traditional cow-calf operation except that the calves are kept on pastures or rangeland instead of being finished in feedlots. To reach market weight, weaned calves (yearlings) must remain in the pastures for an additional year or more. It's challenging to finish cattle on rangeland because the nutritional quality of forage varies from season to season. Dry summer and fall forage lacks some of the nutrients needed to support growing animals, so ranchers who want to produce a grassfinished product must either feed them on high-quality hay or delay finishing the animals until spring forage growth is available. Grassfed and -finished cattle can be 2 to 3 years old at slaughter, whereas feedlot cattle are typically finished at 18 to 24 months.

If ranchers are using the rangeland to finish cattle as well as support mother cows, they need to reduce the size of their cow herd in order to accomodate the young cattle. The only way to add finishing cattle and still have more mother cows would be to buy or lease additional grazing land. Ranchers maintain healthy rangeland by making sure they don't stock it with an excessive number of animals.

\section{Dairy beef}

Although dairy production in the San Francisco Bay Area is limited to the North Bay, California as a whole is the largest dairyproducing state in United States. Like beef cattle, dairy cows are generally bred to have one calf a year. The male calves and some of the females that are not kept for replacements for dairy production are typically raised and finished for beef in a feedlot.

Ranchers and cattle ranches are an integral part of California's history and also play an important role in the conservation and management of open space and park lands. Cow-calf operations have been the dominant method for beef cattle production on California's annual rangelands because of the variability in forage quality and the long dry season that provides just enough feed quality to maintain the cows. The cow-calf operation that produces an annual calf crop for a rancher is the backbone of the beef cattle industry, but it requires additional enterprises such as a stocker operation or a feedlot to develop the eventual consumer products: beef and beef by-products.

\section{End of the Trail}

So, as a cow at home on the range, that's my story. My cow-leagues and I are part of the rich history of California rangelands, living a simple life under blue skies, in fresh air and open spaces, much like our European ancestors did. We're doing our part to help maintain wildlife habitat and a healthy park landscape. I hope you enjoy visiting our shared public park lands as much as we enjoy living here. That's enough talking for now, though-I can see some tastylooking grass just over there, so it's time for me to mooove along!

\section{Glossary}

animal unit (AU). Generally accepted as a mature cow with calf or their equivalent. Animal units are used to calculate stocking rates and may be used to determine lease payments.

bull. An uncastrated male bovine.

cattle. Domesticated species of the genus Bos, also referred to as bovines.

cow. A mature female bovine that has had a calf; more generally, any domestic bovine animal, regardless of sex or age.

forage. Plant material eaten by grazing livestock.

heifer. An immature female bovine that has not had a calf.

range. Rangeland that is grazed by livestock.

rangeland. Land on which the native or natural vegetation (climax or natural potential) is predominantly grasses, grasslike plants, fortes, or shrubs.

steer. A castrated male bovine. 


\section{References}

Barry, S. J. 2014. Using social media to discover public values, interests, and perceptions about cattle grazing on park lands. Environmental Management 53:454-464.

George, M., and D. Lisle. 2009. Stocking rate and carrying capacity. Ecology and management of grazing: An online course. Module 4: Ranch operations and grazing management. University of California Division of Agriculture and Natural Resources.

Huntsinger, L., J. W. Bartolome, and C. M. D’Antonio. 2007. Grazing management of California grasslands. In J. Corbin, M. Stromberg, and C. M. D’Antonio, eds., Ecology and management of California grasslands. Berkeley: University of California Press. 233-253.

Olson, K., J. Waggoner, and J. Jaeger. 2011. Cow side of producing a 1,000 lb. feeder, cow size and expenses. Range Beef Cow Symposium. Digital Commons@University of Nebraska-Lincoln.
To order or obtain ANR publications and other products, visit the ANR Communication Services online catalog at http://anrcatalog.ucanr.edu/ or phone 1-800-994-8849. You can also place orders by mail or FAX, or request a printed catalog of our products from

University of California

Agriculture and Natural Resources

Communication Services

1301 S. 46th Street

Building 478 - MC 3580

Richmond, CA 94804-4600

Telephone 1-800-994-8849

510-665-2195

FAX 510-665-3427

E-mail: anrcatalog@ucanr.edu

(C2016 The Regents of the University of California. This work is licensed under the Creative Commons Attribution-NonCommercial-NoDerivatives 4.0 International License. To view a copy of this license, visit http://creativecommons.org/licenses/by-nc-nd/4.0/ or send a letter to Creative Commons, PO Box 1866, Mountain View, CA 94042, USA.

Publication 8526

ISBN-13: 978-1-60107-920-6

The University of California, Division of Agriculture and Natural Resources (UC ANR) prohibits discrimination against or harassment of any person on the basis of race, color, national origin, religion, sex, gender, gender expression, gender identity, pregnancy (which includes pregnancy, childbirth, and medical conditions related to pregnancy or childbirth), physical or mental disability, medical condition (cancer-related or genetic characteristics), genetic information (including family medical history), ancestry, marital status, age, sexual orientation, citizenship, status as a protected veteran or service in the uniformed services (as defined by the Uniformed Services Employment and Reemployment Rights Act of 1994 [USERRA]), as well as state military and naval service. The University also prohibits sexual harassment and sexual violence.

An electronic copy of this publication can be found at the ANR Communication Services catalog website, http://anrcatalog.ucanr.edu/.

UC This publication has been anonymously peer reviewed for technical accuracy PEVR by University of California scientists and other qualified professionals. This review process was managed by ANR Associate Editor for Animal, Avian, and Veterinary Sciences Carol Collar.

web-1/16-WJC/SB/BG 